\title{
Corporate Manslaughter: Identifying Criminal Liability Under Nigerian Law
}

\author{
Ufuoma Veronica AWHEFEADA PhD (Law) Iroro AKPODOVHAN, LL.M., \\ Delta State University, Abraka,Nigeria. \\ Faculty of Law (Oleh Campus)
}

\begin{abstract}
:
In Nigeria, the concept of corporate criminal liability is slowly catching up with what is obtainable in some jurisdictions where corporations having been recognized as separate entities are criminally liable for the offence of manslaughter. Over a period of time, an increasing number work place fatalities as well as deaths which can be traced directly or indirectly to the activities of corporate organisations. There is an urgent need to examine what the position of the law is with regards to such incidents. This paper therefore seeks to address this gap by considering the criminal liability of corporations and the extent of such corporate liability in the commission of the offence of manslaughter under Nigerian law. In furtherance of this, it attempts an analytical review of the above issues taking into consideration the state of the law in the United Kingdom. The paper concludes by noting that since the offence of corporate manslaughter is not provided for in our Criminal Code, with necessary prescribed punishment, then the Corporate Manslaughter Bill be expeditiously reviewed and passed into law.
\end{abstract}

Keywords: Corporate manslaughter, Criminal liability, Identifying, Criminal Code, Corporate Manslaughter Bill. DOI: $10.7176 / \mathrm{JLPG} / 98-13$

Publication date:June 30th 2020

\section{INTRODUCTION}

Corporate manslaughter is an offence of involuntary manslaughter committed by a corporation through negligence. Over the years, corporations have been responsible for the death of persons through their activities and policies ${ }^{1}$. The status of a corporation as an artificial person is irrelevant to the question of liability. The actions and intentions which constitute the actus reus and mens rea of the crime must, it is said, be those of a natural person, since a company itself cannot commit the constitutive elements of the crime. ${ }^{2}$ Liability is thus independent of the requirement of fulfilling any mental element for such offence.

The first case reported of the problem seems to be in in Suttons Hospital. ${ }^{3}$ After a hesitant beginning, the courts overcame the corporation's lack of mental and physical faculties by imputing the acts, knowledge and intention of its directors, employees and agents to the body corporate. In Leonard Carrying Co. Ltd. v. Asiatic Petroleum Co. Ltd, the Court held thus:

...a corporation is an abstraction. It has no mind of its own any more than it has a body of its own, its active and directing will must consequently be sought in the person of somebody who for some purposes may be called an agent, but who is really the directing mind and will of the corporation, the very ego and center of the personality of the corporation... ${ }^{4}$

The process of ascribing human attributes to a company is essential for the criminal law to do justice. All that needs to be shown is that such an act or omission was perpetrated in the course of the business of the corporation. Therefore, it stems from the above that the activities of corporations need to be regulated and where found guilty, they should be held liable.

Today, the doctrine of corporate manslaughter is recognized in a number of jurisdictions and holds that a company is to be penalized for acts which result in the death of an individual. Penalties, which may vary between jurisdictions, may include a fine, senior management imprisonment and public censorship. This is in addition to awards for civil claims and criminal prosecution of individuals (including employees or contractors). It is punishable because on the one hand, it has the capacity to relate to the consequences of its actions and decisions as well as appreciate the moral blemish of the criminal sanction (therefore it does not have an exculpatory defence) and on the other hand, it can be deterred, rehabilitated and incapacitated. ${ }^{5}$

In Nigeria there has been high record of corporate manslaughter through plane crash, ${ }^{6}$ oil

\footnotetext{
${ }^{1}$ See Almond, P., An Inspector's Eye-View: The Prospective Enforcement of Work Related Fatality Cases, (2006), 46 British Journal of Criminology, 893-916; available at https://doi.org/10.1093/bjc/az1004.

${ }^{2}$ Ford H.A.J, Austin RP, Ramsay IM (2001) Principles of Corporations Law (10th ed), Butterworths, Australia at 673.

3 (1612) 10 Co Rep 23A, 32B.

4 [1915] A.C. 705 at 713

${ }^{5}$ Nana CN (2011) Corporate Criminal Liability in South Africa: The Need to Look Beyond Vicarious Liability Journal of African Law 55 (1) at 101

${ }^{6}$ Olarinde, E.S., Udosen, J., (2020) Corporate Manslaughter Law in Nigeria: A Comparative Study Beijing Law Review 11(1) $<$ https://www.scirp.org/html/23-3300898_99286.htm > accessed April 29 2020. An instance that a company may be prosecuted and convicted
} 
spillage, ${ }^{1}$ explosion from oil pipelines ${ }^{2}$, tankers $^{3}$ and collapsed buildings ${ }^{4}$ amongst others. These tragic events have once again brought the issue of corporate homicide into the spotlight.

In view of the above, this paper examines the law on corporate manslaughter under the Criminal Code and the Companies and Allied Matters Act (CAMA) $)^{5}$ for instances in which a corporation can be held criminally liable for the offence of homicide and also the possibility of sanctioning a corporation by imposing specific prescribed punishment codified under the law commensurate with the offence of manslaughter committed by such corporations.

\section{CORPORATE STRUCTURE AND MANAGEMENT}

A corporation even though a legal person remains an artificial person and it cannot organize and conduct its affairs except through the agency of human beings. A company's policies can be formulated and decided upon by human beings and can be put into effect and carried out only by human agencies. In other words, corporate administration depends largely on the law of agency. In Bamgboye v. University of Ilorin, ${ }^{6}$ Ogundare, J.C.A. as he then was, stated thus:

A director is an agent of his company. In view of the position occupied in the conduct of the affairs of the corporation, he is considered to be the brain and nerve centre which controls what the corporation does.

In First Bank of Nigeria PLC v. Aboko a company was regarded as an artificial person who only exists in the eyes of the law and can only operate by means of human beings.

On his part Gower ${ }^{8}$ stated that:

... both the general meeting and the Board of Directors are organs, rather than agents of the company" and "both the general meeting and the board may be the company: the former when acting under the reserved powers, the latter when acting under an express or general delegation.

Section 63 of CAMA provides that a company shall act through officers or agents who must have been appointed with the authority of the members in general meeting or of the board of directors. The respective powers of the members in the general meeting and the board of directors are usually determined by the company's articles. The probable organs of a company are, therefore, as follows:-

(1) The general meeting of shareholders

(2) The Board of Directors

\subsection{The General Meetings of Shareholders}

The general meeting comprising of all the shareholders is the supreme organ of the company and the primary organ through which the members of the Company exercise their function of surveillance and direction of the Company's administration placed upon them by the CAMA. The general meeting retains the ultimate control of the company through its powers to amend the articles and to remove the directors for whatever reason recognized by its articles or law and by an ordinary resolve and substitute others.

The company in general meeting has the primary duty to appoint the members of the board of directors as provided in section 248 of CAMA and if it is dissatisfied with the actions of the directors it may either alter the articles to remove such powers or it may remove the directors in exercise of its powers under section 262(1) of CAMA and appoint new ones, but it cannot usurp the powers of the directors, or perform their functions.

on a charge of manslaughter is the airplane crash of 2012 in Nigeria involving Dana Airline. The plane was not airworthy and developed dual engine failure because maintenance was not done before embarking on flights. The plane killed 153 people on board, six other persons on the ground were killed while 6 other residents on the site of the crash were declared missing.

${ }^{1}$ Recent oil spills in Delta and Bayelsa States, Nigeria in Delta State.Ten Ijaw communities along the Escravos river in Warri South West Local Government Area of Delta State have been affected by a crude oil spill from a Nigerian National Petroleum Corporation (NNPC) facility. The spill occurred on August $17^{\text {th }}$ 2016,. In Bayelsa State, according to local residents, primarily the Kalaba community which has been recently plagued by gas leaks, a spill was discovered in August 2016, which continues to spill crude oil into the forests and swamps, threatening local ecosystems and agriculture capacity <https:/www. stakeholderdemocracy.org/recent-oil-spills-in-delta-and-bayelsa-statesnigeria/> accessed April 282020.

${ }^{2}$ Reed, E., Pipeline Explosion Blamed on Thieves: A pipeline exploded in Abule Egba at around 8 pm on January 192020. According to the Lagos State Emergency Management Agency (LASEMA) it was brought under control by 9 pm and declared extinguished at 11:30 pm. In addition to the five reported dead, an unknown number of people are in hospital in critical condition.<https://www.energyvoice.com/oilandgas/africa/219233/lagos-pipeline-explosion-blamed-on-thieves/> accessed April 23 2020.

${ }^{3}$ Dozens Die in Petrol Tanker Blast in Nigeria: At least 45 people were killed after a crashed fuel tanker exploded in Benue State in northern Nigeria on Monday. The driver of the tanker had lost control of the vehicle after trying to dodge a pothole. At least 10 bodies have been recovered and at least 70 people suffered serious fire burns. <https://www.bbc.com/news/world-africa-48838108> accessed April 222020.

${ }^{4}$ Nigeria: 13 Building Collapse Incidence Kills 29, Injures 76 in 2019. Twenty nine people died while 76 sustained injuries from 13 building collapse incidents across the country between February and May, 2019.< https://allafrica. com/stories/201906030071.html> accessed April 272020

${ }^{5}$ Companies and Allied Matters Act, Cap. C20, Vol.3.Laws of the Federation of Nigeria, 2004.

${ }^{6}$ [1991] 8 NWLR (pt.207). at 1.

(2007) I.N.W.L.R. at 149

${ }^{8}$ Gower, L.C.B., (1997) Principles of Modern Company Law $\left(6^{\text {th }}\right.$ ed). London: Sweet \& Maxwell Ltd at 132. 


\subsection{The Board of Directors}

Sections 244, 245 and 567 of CAMA define a director as one who manages the affairs of the company. In practice, the initial constitution of the company will provide for the appointment of a board of directors and expressly delegate all powers of management to them. The old idea that the general meeting alone is the Company's agents or servants, at all times subservient to the general meeting, seems no longer to be the law as it is certainly not the fact. It should however be noted that authority to exercise the company's power is delegated not to the individual directors, but only to the directors as a board, although it may be sub-delegated to the managing director or to other officers.

In Shaw \& Sons (Salford) Ltd v. Shaw, ${ }^{1}$ Greer L.J., stated the position as follows:

A company is a separate entity from its shareholders and its directors.

Some of its powers may be exercised by the directors according to its articles: certain other powers may be reserved to shareholders at general meeting. If management powers are vested in directors, these powers can be exercised by them and they alone.. The only way in which the general body of the shareholders can control the exercise of the powers, vested by the articles in the directors is by altering their articles, or, if opportunity arises under the articles, by refusing to re-elect the directors of whose actions they disapproved.

Furthermore, in Bamgboye v. University of Ilorin, ${ }^{2}$ Ogundare, J.C.A. as he then was, stated that: A director is an agent of his company. In view of the position occupied in the conduct of the affairs of the corporation, he is considered to be brain and nerve centre which controls the corporation.

As provided in section 63 (2) of CAMA, the articles normally set out the powers of the directors and once the powers have been vested in the directors, no other person or body is authorized to exercise those powers. Sections 63(3)(4) CAMA allude ${ }^{3}$ to this.

In Shell Petroleum Development Company of Nigeria Ltd v. Allaputa, ${ }^{4}$ it was stated that if a document is signed by the alter ego of a company, sealing is no longer a sine qua non to the validity of the same since its purpose is to ensure that the right person entered into an agreement on behalf of the company. Also in Universal Trust Bank v. Koeoso, ${ }^{5}$ the issue was on the status of chairman and board of directors and managing director of a limited liability Company. Agbo J.C.A. stated that the chairman and the board of a limited liability company are the leading officers in the management of a company. They are the leading agents especially in the company's relationship with the larger public.

\section{CORPORATE MANSLAUGHTER AND CRIMINAL LIABILITY}

A crime is an offence which when committed, makes the offender to be liable to punishment under the Criminal Code. ${ }^{6}$ The Penal Code ${ }^{7}$ provides that 'offence' means any offence under any law for the time being in force. While the Criminal Code uses the word 'crime' for criminal conduct liable to punishment, the Penal Code uses the word 'offence'. It is submitted that both words mean the same thing and have the same effect.

Corporate crimes may thus refer to the criminal liability of the corporate entity. ${ }^{8}$ It may also refer to the criminal conduct and liability of an agent of the firm or corporation. ${ }^{9}$

In Proprietary Articles Trade v. A.G. Canada,${ }^{10}$ Lord Atkin said that an act can only become a crime if an act is punishable. Therefore, punishment is a feature of crime. Garba J.C.A. in the case of Odon v. Barigha-Amange ${ }^{11}$ defined crime as an offence which is punished by law or activities that involve breaking the law or prohibited by

\footnotetext{
1 [1935] 2 K.B. 113 at 134

${ }^{2}$ (1991) 8 NWLR (Pt. 207) at 30. For a discussion of the case. See Apori K.A., (1993) Agency and Hire Purchaser Law: Nigeria Perspectives Ile-Ife, Emiola Publishers at 88.

${ }^{3}$ Section 63(3) of CAMA states thus:Except as otherwise provided by the Company's articles, the business of the Company shall be managed by the board of directors whom may exercise all such powers of the Company as are not by this Act or the articles required to be exercised by the members in general meeting. While, Section 63(4) of CAMA provides that, Unless the articles shall otherwise provide the board of directors, when acting within the powers conferred upon them by this Act or the articles, shall not be bound to obey the directions or instructions of the members in general meeting. Provided that the directors acted in good faith and with due diligence.

${ }^{4}$ (2005) 9 N.W.L.R. (Pt 931) at 486.

5 (2006) 18 N.W.L.R (Pt 1010) at 8.

${ }^{6}$ CAP C3I, Laws of the Federation of Nigeria, 2004

${ }^{7}$ CAP P8, Laws of the Federation of Nigeria, 2004.

${ }^{8}$ Reasons, C., (1991) Crime Against The Environment: Some Theoretical and Practical Concerns. Vol. 34 Crim. L.Q. at 86-92.

${ }^{9}$ See Moor, G.S., (2007) On the Prospects of Deterring Corporate Crime University of Houston Public Law and Legal Theory Series A-37. He goes further to explain that, although the two meanings seem somewhat related, it is also important to distinguish misconduct at the corporation from misconduct by the corporation. Indeed the firm is not always the perpetrator. A corporate entity or firm may as well be the victim of an agent's misconduct and in some cases may be both a victim and the perpetrator.

${ }^{10}$ [1931] A.C. 310 at 324

11 [2010] 12 Nigerian Weekly Law Reports, 13CA, (Pt1207) at 1-206.
} 
the law.

According to Smith and Hogan, ${ }^{1}$ it is very difficult to define crime. However, an interested person is entitled to know the meaning of crime or why it is difficult to define or comprehend. In an attempt to define crime one encounters a serious difficulty. Allen, ${ }^{2}$ states that: 'Crime is crime because it consists of wrongdoing which threatens the security and wellbeing of the society and because it is not safe to redress it by making recourse only to compensation. In other words crime is a public wrong.' Wells, ${ }^{3}$ on her part states that the term 'Corporate Crime' describes corporate activities as those activities which are perceived to involve a transgression of some aspect of criminal law. ${ }^{4}$ She further advances that that the term is commonly used to denote branches of regulatory offences as well as conjures such images as are of fraud and other illegal endeavours which offend against laws which are of general application

Where a company is involved in a criminality, the burden is on the prosecution to prove that it was not the company that is corporately liable but an employer or officer of the company and such burden of proof as in any other criminal case, is proof beyond reasonable doubt. ${ }^{5}$ The expression beyond reasonable doubt does not mean proof beyond all shadow of doubt, it simply means that the evidence of the prosecution against an accused person must be strong and direct, leaving no remote possibility which can be dispensed with. In other words, the prosecution is required to produce positive and credible evidence which must be direct or if circumstantial, must be of such quality or cogency that a Court could safely rely on it to decide the case. ${ }^{6}$

In the case of Adenuji v. State, ${ }^{7}$ the Supreme Court held as follows:

In discharging the burden of proof, it is not enough to merely allege that the appellant was the person involved in the criminal transaction which resulted in the criminal conduct, but that he was in fact and in law the criminal. In other words, he committed the crime as an individual, as distinct and separate from the company.

The Supreme Court further held in Adeniji's case (supra) that the appellant was not personally liable for the crime he was alleged to have committed in that his action which constituted the offence was carried out corporately. This case is authority for the proposition that an individual natural person should not be held personally liable for the acts which apparently were done for and on behalf of the company. ${ }^{8}$

Corporate manslaughter is is a criminal charge against companies where a company is guilty of involuntary homicide; wrongful murder of another person(s). According to Stephen Griffin: ${ }^{9}$

Corporate entity may not be convicted of murder as the sentence imposed on an artificial entity for that offence, namely, a mandatory life imprisonment penalty, is not feasible

The issue as to whether a corporate body could be liable for certain offences like manslaughter came up in $R$ v. HM Coroner for East Kent ex parte Spooner, ${ }^{10}$ where Lord Justice Bingham tentatively held that both a company and an individual could be liable for an indictment.

In $R v$. Pittwood, ${ }^{11}$ the accused, a level cross keeper failed in breach of his contract of employment to close the gate when a train was approaching with the result that someone was killed on the crossing. The accused was convicted of manslaughter after Wright $\mathrm{J}$. had held that a person might incur criminality liability from failure to perform a duty arising out of contract and that duty could be owed to road users even though the contractual obligation was only owed to the railway company. It must be emphasized that, even if the actus reus of an offence is constituted by an accused's failure to fulfill a duty to act, he cannot be criminally liable unless his omission was accompanied by the relevant mens rea.

Turner $\mathrm{J}$, in his concluding remarks on corporate liability in $R$ v. $P \& O$ European Ferries $L t d,^{12}$ affirmed that a company can be convicted for manslaughter thus:

... a person who is the embodiment of a corporation acting for the purposes of

the corporation may also be found guilty of the act or omission which caused

the death of the corporation, the corporation may also be found guilty for manslaughter.

He further enthused thus:

where a corporation, through the controlling mind of one of its agents, does

\footnotetext{
${ }^{1}$ Smith and Hogan (1993) Text, Cases and Materials on Criminal Law ( $8^{\text {th }}$ ed). Butterworths,Britain at 137.

${ }^{2}$ Allen C.K., (1933) The Nature of Crime and Society of Comparative Legislation (3rd ed). Oxford University Press, 1933 ) at 64.

${ }^{3}$ Wells, C., (2001) Corporations and Criminal Responsibility (2nd ed). Oxford: Oxford University Press at 148.

${ }^{4}$ Ibid.

${ }^{5}$ Adedokun, E., (2014) Defences to Criminal Liability in Nigeria Alvari Communications Limited, Adamawa at 182.

${ }^{6}$ See the cases of Amodu v. State (2010) 2 NWLR (Pt.1177) at 69. Adetola v. The State (1992) 4 NWLR (Pt.235) at 267.

${ }^{7}$ (1992) 4 NWLR (Pt. 234) at 248.

${ }^{8}$ See also Esangbedo v. State (1989) 4 NWLR (Pt. 113) at 57 and Karimu v. The State (1981) 1NWLR (Pt.96) at 124.

${ }^{9}$ Griffin, S., (2009) Corporate Killing, the Corporate Manslaughter and Corporate Homicide Act 2007 L.M.C.L.Q., 72 at 74.

${ }^{10}$ (1987) 88 Cr App R 10.

11 [1902]19 T.L.R.37

12 (1991) 93 CAR 72
} 
an act which fulfils the prerequisites of the crime of manslaughter...it as well as its controlling mind or minds is properly indictable for the crime of manslaughter.

This sent a clear and unequivocal message that corporate immunity had no place in the legal community and companies could be held liable for crimes intended to address individual liability.

Nevertheless, there appears to be some judicial invention for the basis for corporate criminal liability because from the decision of Birgham LJ in the Herald of Free Enterprise ( $R$ v. HM Coroner for East Kent ex parte Spooner) ${ }^{l}$ (on an application for a judicial review in the Queen's Bench Divisional Court), a tacit acceptance that a corporate body could be liable for the offence of manslaughter could be inferred. He said:

The mens rea required for manslaughter against the corporation

can be established on appropriate facts. I see no reason in principle

why such a charge should not be established. Whether the defendant

is a corporation or a personal defendant, the ingredients of

manslaughter must be established by proving the necessary mens rea

and actus reus of manslaughter against him by evidence properly relied.

According to Mueller:2

Why should not a corporation be guilty of murder where, for instance corporation's resolution sends the corporation workmen to a dangerous work place, without protection, all the officers secreting from these workmen the fact that even a brief exposure to the particular work hazards will be fatal as was the case in the notorious Hawk's West venture in West Virginia, where wholesome death (as in Bhopal's case in India) was attributed to Solicosis?.

At common law, a corporation could therefore be be convicted of involuntary manslaughter by gross negligence, even though homicide has not been classified as a distinct offence. In convicting for manslaughter, the House of Lords ${ }^{3}$ has held that in convicting for manslaughter that it is sufficient for the jury to adopt the gross negligence test without reference to the test of recklessness as defined in the case of $R v$. Lawrence. ${ }^{4}$ So the ordinary principles of law of negligence must still apply in ascertaining whether or not a corporation has been in breach of duty of care to the victim who has died. Where such is established, the next question would be whether that breach of duty caused the death of the victim. The jury need to determine that the degree of which the actions of the company differed from the normal standard of care fairly required of it in the circumstances of the case, and this need not cause the danger of injury to the victim, was such that it could be deemed criminal. ${ }^{5}$. Recently, the corporation itself could not be accused of criminal negligence, unless it is found that the individuals, who can be identified as the directing mind and will of the corporation, are themselves guilty of gross negligence. This is known under the common law as the "identification principle." And because a corporation's artificial nature makes it incapable of committing a physical act that is a prerequisite for the offence of manslaughter, corporate liability for involuntary manslaughter was ascertained in accordance with the identification principle. Under the common law, identification model offences of individual senior officers and employees are imputed to the corporation on the basis that the state of mind of these officers and employees are that of the corporation. This is otherwise known as the "Alter Ego" doctrine or the "Organic theory". In every corporation, there are certain individuals who control and direct the activities of the company. They are considered the embodiment of the company such that their acts and state of mind are that of the company. The company could thus be held liable, not for the acts of these principal officers or servants, but for what is deemed to be the company's own acts. The judicial development of this is traceable to the popular words of Viscount Haldene L.C in the well-known case of Lennard Carrying Company v. Asiatic Petroleum Ltd. ${ }^{6}$

In $R v$. Corry Brothers Ltd., ${ }^{7}$ the Directors of a company decided to create a fence around a power house belonging to the company to prevent pilfering from it. Accordingly, a wire was erected and charged with electric current on the instruction of the power engineer of the company. Soon after, on the same day, the deceased accidentally stumbled on the fence and died. The company was then charged with the offence of manslaughter. The court, however, held that the company could not be held guilty of manslaughter or for the offence of setting traps with the intent to inflict grievous bodily harm. This judgment seems to have done away with the alter ego principle, which makes the act or intention of some highly placed officers of the company (e.g. directors) the acts and intentions of the company. Otherwise, how else would the corporation be involved in the manslaughter than

1 (1989) 88 Cr App R 10

${ }^{2}$ Emem, C.E. and Uche, A.P., (2012) A New Dawn of Corporate Criminal Liability Law in The United Kingdom: Lessons For Nigeria African Journal of Law and Criminology $2(2)$ at 86-98.

${ }^{3}$ See $R$ v. Adomako (1994) 3 All ER 79.

${ }^{4}$ (1981) 1 All ER 974. Although it is still open to the trial judge to use the word 'reckless' in its ordinary meaning in particular circumstances.

See Lord Mackay's statement in $R v$. Adomako (supra n.39).

${ }^{6}$ (1915) A.C 705.

7 [1927] 1 KB 810. 
through the intentional acts of its high officers like directors as in this case.

In contrast to the above judgment, a court of the United States of America adopted the view that corporations could be prosecuted and found guilty of manslaughter. Thus, in Granite Construction Company v. Superior Court. ${ }^{1}$ In a charge of manslaughter, the corporation argued that as an economically motivated entity, it could be liable only for property crimes. The court responded:

This argument is unsuccessful. It overlooks the substantial indirect economic benefit that may accrue to corporation through crimes against the person. To get these economic benefits, corporate management may short cut expensive safety precautions, respond forcibly to strikes or engage in criminal anti competition behavior.

Accordingly, a corporation could be liable for the offence of involuntary manslaughter where a person's death was caused by gross negligence of the corporation's directing mind. It must be noted however, that the charges against a particular defendant cannot be amplified by evidence against another defendant. In other words, a case can only be brought against a corporation by evidence properly addressed to show guilt on the part of the corporation as such so that the evidence against the corporation can only consist of evidence related to the directing mind and will. ${ }^{2}$ This is called the rule against 'aggregation'. As it has been argued, a corporation could therefore escape conviction for involuntary manslaughter in circumstances where an individual representing the company's directing mind was incapable of being convicted for involuntary manslaughter. ${ }^{3}$

But the identification principle is not without some difficulties. For a corporation to be found criminally responsible for manslaughter, a senior individual or individuals within the corporation must be held to be similarly liable. A culpable individual with a 'directing mind' must be identified before the corporation can share their guilt. ${ }^{4}$ The main complex task has remained the formula to be employed in knowing what category of workers is to be considered as the "directing mind" or "alter ego" of a corporation..$^{5}$ If it is conceded that the obvious place to look at is the company's memorandum of understanding and articles of association, it may further amount to hair splitting to try to draw a line separating the alter ego of a corporation from its mere agents. And the nature of modern multinational corporations is that such powers and duties are spread across departments and sections. In such situations there may be obvious problems in the allocation of responsibilities and liabilities within the higher echelons of a corporation. It would appear that, these lapses in the identification model prevented the prosecution from sustaining successful prosecutions against companies for the offence of involuntary manslaughter because up till date there has been a dearth of cases where a public company has been convicted for involuntary manslaughter in England. ${ }^{6}$ Griffin has also attributed this failure to the hierarchical complex management structures of big corporations when he argued that:

[T] he failure to prosecute public companies may be explained in the context of complex management structures of large corporations, which frequently result in a dilution of any causal link between a culpable employee and company's directing mind. In a large corporation, corporate policy and implementation of corporate powers flowing from directing mind may become misinterpreted, confused or abused by lower tiers of management. Although the wrongful act or omission of an employee may have been linked to the instructions of a more senior employee, the act or omission would often be considered devoid of any direct and binding authority from the directing mind.

Thus, in Tesco Supermarket Ltd v. Nattrass, ${ }^{7}$ Tesco evaded liability simply because the store manager could not be regarded as part of the company's directing mind, nor had the store manager been delegated an authority by the directing mind to act in a manner contrary to the company's policy. The facts of the case is that Tesco Supermarket had advertised and made a very low-price offer on a specific product through a poster that was pasted on its shop. But when the said product was lacking in supplies at that relevant time, Tesco forgot to remove the said advertisement. When the unfortunate customer has seen a higher price stock already on the shelves, he mistook it for the said lower price product and was charged the full price. Thinking that he was deceived by misleading prices, the customer brought an action against Tesco for breach of Trade Descriptions Act 1968. Tesco contended that it was not to blame since it was the act/omission of the store manager. Affirming Tesco's contention, the court

\footnotetext{
${ }^{1} 149$ Cal. App. $3^{\text {rd }} 465,197$ Cal. Rptr. 3 (1983).

${ }^{2}$ Griffin (supra n.33) at 75 .

3 Ibid.

${ }^{4}$ See Welsh, R. S., (1946) Criminal Liability of Corporations $\quad$ Law Quarterly Review at 347.

${ }^{5}$ Those who wield corporate powers or the senior management such as directors, managing director, general manager, and even secretary have been considered as a corporation's alter ego. For example in $R$ v. I.C.R. Haulage Ltd (1944) 2 All E.R. 515, a company was held liable for conspiring to defraud by the acts of its managing director.

${ }^{6}$ The first known recent case being $R$. v. Kite \& OLL Ltd (1994) 99 Cr. App. R. 362. Here, a company that organises canoe trips was convicted for manslaughter (through its managing director) for the death of four students who drowned as a result of the gross misconduct of the managing director

7 (1972) AC 153
} 
therefore held that the company was not liable, rather it was the individual store manager, who though worked for Tesco, could not be considered the 'directing mind and will' to impose liability on Tesco as a company. In other words, attempts at identifying and sanctioning key responsible officers in a corporation have always been a herculean task. Owing to the fact, that in recent times there has been an upsurge of series of human disaster, accidents and deaths in which corporations have been found to be at fault ${ }^{1}$ (though no major company has been convicted), the debate and call around the world for the reform of the legal principles governing corporate criminal liability in general and corporate manslaughter in particular, has gathered momentum. The UK recently responded to this call by the birth of 'Corporate Manslaughter and Corporate Homicide Act $2007 .{ }^{2}$ In Nigeria however, the Corporate Manslaughter Bill is yet to be passed into law.

Section 1(1) of the Corporate Manslaughter Bill of Nigeria ${ }^{3}$ indicates that the offence is committed where the organization's activities are managed or organized in a manner that results in a person's death and that such death must be caused by a gross breach of the organization's relevant duty of care. By its definition of Corporate Manslaughter, before a company can be convicted or held liable for an offence, ${ }^{4}$ three (3) key factors must coexist, i.e. death, gross breach and the appropriate duty of care. These factors would now be considered in detail.

i. Death -Before an organization can be held responsible for corporate manslaughter, death must have been the result of the organization's act or omission. Therefore, a company would not be prosecuted for attempting to commit corporate homicide irrespective of how risky its activities are handled. Guilt may be established only where the manner in which an organization's activities are managed or organized by its senior management is a significant factor in the breach of the relevant duty of care. In Sowemimo v. State, ${ }^{5}$ it was held that to sustain a conviction of the offence, it must be established beyond reasonable doubt, it was the defendant's act that induced the deceased's death. In all cases, where death is alleged to have been the result of the person's actions, a causal link between death and the act must be established in criminal proceedings beyond reasonable doubt.

\section{ii. Relevant Duty of Care}

The Corporate Manslaughter Bill, 2010 (CMB) sets out the "relevant duties of care" owed by organizations. The duty of care also apply to employees who are being detained or transported by law enforcement agencies and those who live in safe housing. Whether a duty of care is owed to a particular individual is a matter of law and the judge is required to make the factual findings necessary for the decision. ${ }^{6}$

Having regard to the scope of persons covered by the relevant duty of care provisions under the bill, it would appear that the neighborhood principle in torts has been plainly codified in the bill. That a person is expected to take reasonable caution by this concept to prevent actions or omissions that he can fairly predict as likely to cause harm to his neighbour. In the famous

English case of Donoghue v. Stevenson ${ }^{7}$ where the principle was laid down, Lord Atkin defined a neighbour to include all persons who are likely to be directly and closely affected by one's act or omission, so that the person performing the act should reasonably think of them when engaging in the act or omission at issue

It is worthy of note that section 2(6) of the CMB expressly excludes any rule of common law which has the effect of preventing or restricting a duty of care from being owed by reason of acceptance of risk, harm or engagement in an unlawful conduct. The implication of this provision is that a corporate organization remains liable, in spite of the fact that the person affected by the act or omission was engaged in an unlawful act or accepted to engage despite his knowledge of the risks involved. What is significant is that the company carried out its operations in a way that resulted in death and death due to a severe violation of a related care obligation. By that, the application of the "volenti non fit injuria" common law principle appears to have been excluded. The principle is a defence in tort with the effect that if a person who is aware of the risks inherent in an activity accepts to engage in that activity, he cannot subsequently complain or seek compensation for an injury suffered during the activity. In any event, it is the responsibility of the courts to determine whether or not an organization owes a duty of care to any person in the activity.

However, under sections 3 and 4 of the $\mathrm{CMB}$, the following will not constitute relevant duty of care for the purposes of holding corporate bodies criminally accountable for the offence of corporate manslaughter:

\footnotetext{
${ }^{1}$ See for example., the UK's 1997 Southall Rail crash, in which seven persons died; the 1999 Paddington (Ladbroke Grove) crash, in which 31 people died as well as the 2000 Hatfield Rail crash, in which four persons died.

2 It was brought into force on April 6, 2008.

${ }^{3}$ Corporate Manslaughter Bill for an Act to Create the Offences of Corporate Manslaughter and Matters Incidental Thereto, 2018, (CMB, 2018).

${ }^{4}$ Ugbeta. E., The Lawyer Chronicles, An Assessment of The Corporate Manslaughter Bill 2015 as Drafted and its Implications For Corporate Entities in Nigeria <Thelawyerschronicle.Com/An-Assessment-Of-The-Corporate-Manslaughter-Bill-2015-As-Drafted-And-ItsImplications-For-Corporate-Entities-In-Nigeria/>Accessed April 302020.

${ }^{5}$ [2004]11 NWLR Pt. 885, 515 at 534.

${ }^{6}$ Osemobor v. Niger Biscuit Limited (1973) NCLR 382

7 (1932) AC 562.

8 Meaning "to a willing person, injury is not done".
} 
1. Duty owed by a public authority with regard to decisions on public policy matters. For example, public resources allocation or the weighing of competing public interests; 2 . Duty owed for the exercise of sole public function; 3. Duty owed by a public authority in the exercise of a statutory function in respect of inspection carried out; 4 . The Ministry of Defence's duty with regard to general military operations and training; 5.Duty owed by the Police Force in respect of policing and general law enforcement activities; and 6. Duty owed by rescue organizations in responding to emergency circumstances.

\section{iii. Gross Breach}

Gross breach on the other hand is defined under section 1 (4) (b) of the CMB as a conduct which falls far below what could be reasonably expected of the organization in the circumstances. In other words, the subjective reasonable man's test is to be applied for the purposes of determining if the activities of an organization constitute a gross breach to ground a conviction. On establishing the existence of a duty of care by an organization, the court must consider whether the organization failed to comply with any health and safety legislation relevant to the alleged breach and if so, how serious that failure was and how grave a risk of death it created. The court may also consider the extent to which attitudes, policies, systems or accepted practices within the organization were likely to have encouraged any such failure.

It should however, be noted that by of section 1(3) of the CMB, before the activities of an organization would be regarded as constituting a gross breach of the relevant duty of care, such activities must be managed or organised by the organization's senior management and must also constitute a substantial element of the breach. What this suggests is that an organization would not be considered to have committed the offence where the act or omission that resulted in the offence was performed by the organization's lower level employees and not sanctioned by the organization's senior management. Nevertheless, no individual (senior management or otherwise) would be personally convicted for helping,encouraging,counseling or procurement or being a party to the offence commission. Section 16 of the $\mathrm{CMB}$ exempts individual liability in all cases, no matter how substantial the individual's contribution may be in the commission of the offence. For a successful conviction, the prosecution must show that grossly negligent reckless acts or omissions of the company were performed by the person(s) who are the company's "controlling mind(s)" and whose actions result in the immediate cause of death of its employees or other persons using their services for the public.

Corporate homicide will therefore mean a situation where the acts or omission causing death occurred as a result of the systemic misconduct of a corporation, and the corporation is the truly blameworthy party and not the individual members of the corporation.

Worth mentioning is that the Nigerian Criminal Code deals with criminal responsibility in section 24 . It provides:

Subject to the express provisions of this Code relating to negligent acts

and omissions, a person is not criminally liable for an act or omission thatoccurs

regardless of the exercise of his will, or for an accident that

occurs. Unless the intention of causing a particular outcome is expressly

declared as an element of the offence constituted, in whole or in part, by an act or omission, the outcome intended to be caused by an act or

omission is irrelevant.Unless expressly stated otherwise, the motive for a person to do

or omit an act or to form an intention is irrelevant in so far as criminal responsibility is concerned..

The above explains criminal responsibility under the Code. First, the physical element is recognized to be in the form of an act or omission. It covers acts that occur independently of the will of the accused. Second, the requirement for the mental element is explained in three ways as follows. The first paragraph means that there can be no liability without fault. The word "will" in the paragraph means the accused's intention and awareness of the circumstances connected to the act. The second paragraph provides for result offences and simply denotes the common law rule on presumption of mens rea that unless intention is expressly stated as part of the definition of an offence, it is immaterial that the accused intended to cause a different result.

Also, the wordings of section 24 show a presumption against vicarious liability for a mental element.It states a person is said not to be liable for an act that takes place without the exercise of his will. This is in tandem with the principle that personal liability is the hallmark of criminal responsibility. Therefore, from these provisions, the mens rea or mental element is recognized.

In Arab Transport v. Police, ${ }^{1}$ a company was charged with permitting one of its lorries to be used for the carrying of passengers contrary to the existing regulations. The company was acquitted as the offence required proof of mens rea. The court held that the company would only be guilty if it knew that carrying of passengers was a likely consequence of its motor vehicle being used on the highway and yet continued to allow them on the

${ }^{1}(1952) 20$ N.L.R.65. 
road without taking adequate steps to prevent passengers being carried. Also, in Nirchandani v. Prinheiro, ${ }^{1}$ the court held that a principal cannot generally be liable for the fraud of his agent unless it is proved that the respondent had a guilty mind in respect of that offence and had participated in it.

\section{THE CORPORATE MANSLAUGHTER BILL ${ }^{2}$}

The National Assembly has at different times made attempt to pass this Bill into law in Nigeria after haven been passed by both houses of the National Assembly in Nigeria. The latest of these attempts was in 2018 but the final step required for the Bill to become law, that is the assent of the president was declined ${ }^{3}$. It is however important to examine the salient provisions of this Bill to see how it may possibly improve upon the law regulating corporate manslaughter in Nigeria. The scope of application of the bill shall be considered from the point of view of its territorial application, persons and then exemptions. The categories of persons to whom the provisions would apply are specified under section 1 (2) (a) - (d). It applies to only corporate organizations (public or private), Government Departments (Federal, State or Local Government), armed forces, paramilitary and the police force, partnerships, trade unions or employers' association which is an employer. It also applies throughout the Federation of Nigeria and any place within the seaward limits of the territorial sea adjacent to the Federal Republic of Nigeria. It also applies to a Nigerian controlled ship, aircraft and hovercraft and generally any place to which the Petroleum Act applies. By section 18, the liability of the owners of a Nigerian controlled ship and aircraft continues even when the person affected is no longer on board so long as the injury resulting in death was sustained while on board.

Section 1(5) provides that the punishment for the offence of corporate manslaughter upon conviction is a fine. However, the amount of the fine to be imposed is not stipulated. The implication of this is that the amount of fine to be imposed in each case is wholly at the Judge's discretion to try the matter. In addition to the enforcement of a penalty, section $8(1)$ authorizes the courts to render remedial decisions by the defendant pursuant to the proceedings to that extent. The remedial order is designed to guide the defaulting company to take specific steps to remedy the health and safety defects within the entity that lead to the execution of the offence. Failure to comply with a remedial order is also an offence which attracts a fine under section $8(6)$. The amount to be imposed as a fine is also not specified.

The court has power under section 9 to order publication of conviction stating that the organization has been convicted and details of the offence and sentence imposed provided.

Also,under section 17, a person convicted of the crime of corporate manslaughter maybe charged and tried on the same set of facts or similar facts for other crimes codified under any health and safety laws.

In the same vein the imposition of criminal sanctions can effectively deter corporations, ${ }^{4}$ as well as rehabilitate and incapacitate them in order to achieve the goals of crime reduction and furtherance of social interest. Deterrence no doubt enjoys consensus as the main purpose of punishing corporations given that even opponents of corporate criminal liability accept that corporations may be deterred by criminal sanctions, ${ }^{5}$ although they also claim that there is unfortunately no standard to determine whether a sanction effectively deters corporate defenders. ${ }^{6}$ Nonetheless, corporations are most likely to be deterred by sanctions that may cause considerable economic $\operatorname{loss}^{7}$ or by an indictment and prosecution and/or sanction that carry a public stigma.

Rehabilitation has in some instances (when coerced) been deemed to be more appropriate to corporate entities than natural persons. ${ }^{8}$ A remedial order may incite a corporation to put in place a compliance programme to correct a defective operation in accordance with the order and re-establish its reputation. In such instance the corporation may be said to have been rehabilitated or reformed. This is also the case where the court thinks it is appropriate in the circumstance to order a re-organization of the managerial structure. This may be achieved in part through orders disqualifying negligent company directors ${ }^{9}$ and compelling other directors to act responsibly and exercise sufficient skill and care with regard to the interests of all the company's stakeholders. ${ }^{10}$

\footnotetext{
1 \{2001\} FWLR (Pt 48) at 1314.

${ }^{2}$ A Bill for an Act to Create the Offences of Corporate Manslaughter and Matters Incidental Thereto, 2018, (CMB, 2018).

3 Henry Umoru, "Buhari Declines Assent to Corporate Manslaughter Bill, 3 Others" Vanguard, July 18, 2018 availabel at www.vanguardngr.com accessed on $4^{\text {th }}$ May, 2020.

${ }^{4}$ See Wells (supra n.27) 13-14

${ }^{5}$ Packer HL (1964) Two Models of the Criminal Process, 113 U. Penn. L. Rev. 1

${ }^{6}$ Byam JT (1982) The Economic Inefficiency of Corporate Criminal Liability 73 J. Crim. L. \& Criminology 582, 584-85. This argument has more to do with the practicality of sanctions than their legitimacy because the same claim may be made of natural persons. Byam employs economic efficiency as a standard to specify a deterrent penalty for corporations (which he thinks should be civil damages) but his analysis is premised on contestable assumptions: a system of enforcement that reduces the incidence of corporate crime will cost less to society and will be more efficient and more effective; and corporations naturally respond to threats of economic sanctions (irrespective of the likelihood of prosecution and conviction).

${ }^{7}$ Ibid. This is logical for profit-making corporations given that they are driven by the desire to maximise profits and might be tempted to commit the crime and include it in their costs if the crime will enable them maximise profits or the sanction is not hefty.

${ }^{8}$ Braithwaite J and Pettit P (1990) Not Just Deserts A Republican Theory of Criminal Justice Clarendon Press · Oxford 199 at 124

${ }^{9}$ See for example in the UK, the Company Directors Disqualification Act 1986 Chapter 46, the Insolvency Act 2000,and the Enterprise Act 2002

${ }^{10}$ Braithwaite J and Pettit P (supra n.66). This may be stated as the reason why criminal sanctions should target the individuals responsible
} 
Worth mentioning are some lacunae prevalent in this bill. The provisions do not apply to natural individuals. It does not impose secondary liability on persons (senior management or other employees of the organization) who might be personally responsible for the death caused. Regardless of how reprehensible a natural person's act or omission appears; regardless of the degree of his / her involvement in the acts or omissions that culminate in the offence, he / she cannot stand trial for personal liability; he/she cannot be convicted for assisting, encouraging, counseling or procuring or being a party to the commission of the offence. An action against an individual can only be prosecuted under other legislation or manslaughter or gross negligence criminal offences, which complicates the prosecutors' work and requires more time and money.

The bill only provides for payment of fine as punishment for the offence. It does not specify a particular amount as fine and this may subject the imposition of fine to gross abuse by the Courts. There is the tendency for the Courts to award ridiculously high amounts that may not be justified by the circumstances of the case.

Furthermore, under this proposed bill, the term 'senior management' is only vaguely defined, leaving unclear the question of who qualifies as such within an organization.

Consequently, the Corporate Manslaughter Bill, 2010 is the first attempt by the Nigerian legislators to put in place a single piece of legislation that creates a means of holding corporate entities criminally liable for the death of employees arising from their acts or omissions. This bill should therefore be passed into law by the National Assembly and assented to by the president without further delay.

\section{THE EXPERIENCE IN THE UNITED KINGDOM (UK)}

In respect of the strict criminal liability on corporation, the English Law Commission in one of its working papers on the criminal liability of corporations has agreed with the principle that bodies corporate should be liable at least in the regulatory field. ${ }^{1}$ The report reads as follows:

the main objective of criminal law is crime prevention and it is argued that the publicity attendant at the company's prosecution has a strong deterrent effect, a company's prosecution for the omission of an offence ${ }^{2}$

The Law Commission ${ }^{3}$ has proposed a special crime of corporate manslaughter. A company is guilty of corporate killing if: a. corporation's management failure is the cause or one of the causes of the death of a person; and thatb. failure involves behaviour that is far below what the company would reasonably expect in the circumstances.

The Corporate Manslaughter and Corporate Homicide Act 2007 (CMCHA) is the first legislation on corporate homicide. The Act was passed essentially to solve the problems of the identification theory and was influenced by the general public outcry which followed the failed prosecution of the Herald of Free Enterprise ${ }^{4}$ and Transco's case $^{5}$ in Scotland. Therefore, it was also aimed to ensure more prosecutions.

The Act. (CMCHA) therefore is a short Act and creates only the single offence of corporate homicide. Therefore, it addresses the challenges of determining the corporate mens rea. Section 1(1) defines the offence as the manner in which an organization's activities are managed or organized causes a person's death and also constitutes a gross breach of the organization's duty of care to the deceased victim. It is fundamental from the provisions of section 1(1) that the death that occurred must have been a result of an infringement of a duty of care. The corporation must be responsible for care to the deceased which must have been breached.

By the above definition of the offence, the actus reus of the offence is therefore acts or omissions which constitute the activities of the corporation. Therefore, acts or omissions of officers or agents of a corporation acting within the apparent and implied scope of employment, done while carrying out the usual business of the corporation shall be regarded as the acts and omissions of the corporation itself.

\subsection{Mens Rea under the CMCHA}

The mens rea or mental element is vested in the management hierarchy of the corporation. Section 1(3) CMCHA explains that a corporation cannot be convicted of the offence unless how it manages its activities by its senior management is a substantial element in the breach of duty of care. Section 1(4)c CMCHA defines senior management as a person who plays an important part in the decision making of the whole or substantial part of the corporation. At a first glance, it seems that this is a passive reference to the identification theory because the senior management looks more or less like the directing mind. However, the combined effect of section 1(3) and (4) $\mathrm{CMCHA}$ allows a broader approach to the identification method because it aggregates the activities of management

rather than corporations. However, there are instances where no single director may be shown to be at fault. Thus, although targeting the corporation only may not always achieve the goals of the criminal law, in many cases involving corporate activities it remains the most efficient strategy.

${ }^{1}$ Tom, D.F. (2005) Criminal Liabilities of Bodies Corporate in Nigeria Law Chenglo Limited,Enugu, at 58.

${ }^{2}$ U.K. Law Commission Working Paper No. 44 (172) 34 at 38

${ }^{3}$ See Herring J and Marise Cremona M (1997) Criminal Law ( $2^{\text {nd }}$ ed). Macmillian, London at 88.

${ }^{4}$ See Herald of Free Enterprise ( $R$ v. HM Coroner for East Kent ex parte Spooner) (1989) 88 Cr App R 10

${ }^{5}$ See Transco P.L.C v. H.M Advocate (2003) G.W.D 38-1039, (2004) S.L.T, 995. 
and not just one or two directing minds. Also, the way the activities of a corporation are managed can actually reflect both the written and unwritten rules of a corporation.

Unlike the identification theory, a corporation that has taken steps to prevent the death will escape liability under the Act. Section 1(4)b of CMCHA provides that a breach of a duty by a corporation qualifies as gross breach if the conduct alleged falls far below what is reasonably expected of such corporation. This aptly captures the corporate mens rea and only a truly guilty corporation will be liable.

The provision of section 8(3) CMCHA is also instructive. It provides for factors for the jury to consider in determining whether there has been a gross breach of duty of care by the corporation. It provides that the jury should consider the attitudes, policies, accepted practices and systems within the organization that encouraged the act constituting the breach of duty of care. It is submitted that the corporate mens rea can in fact be located in the unwritten rules, attitudes and practices of a corporation.

\subsection{Cases Decided Under the CMCHA}

$R$ v. Cotswold Geotechnical (Holdings)Ltds, a landmark case in the United Kingdom, as Cotswold Ltd was the first company convicted under the CMCHA in 2011. In this case, a junior geologist took soil samples in a 3.8 meter excavated pit and caused him to be buried and killed as a consequence of the company's failure to adhere to health and safety measures as the pit collapsed. In his summary, the judge stated that it was "clearly predictable that failure to address the hazard would result in serious injury and indeed could have fatal consequences." As such the company has fallen well short of the expected standard in regards to such a project and as the boss, Mr. Eaton, was in command of the forklift, he was named as senior manager. The firm was convicted and ordered to pay $£ 385,000$ over a period of 10 years

Further in $R v$. Lion Steel Equipment Ltd, ${ }^{1}$ the Court held that:

the defendant...being an organization, namely a corporation, and because of the way in which the organizations' activities were managed or organised by its senior management, caused the death of.....Steven Berry

by failing to ensure that a safe work system was in place for the work carried out at roof height, the failure of which amounted to a gross breach of the duty of care due to the deceased.

Lion Steel Ltd was fined $£ 480,000$ for three years and a half.The respondent company was found guilty of corporate manslaughter in $R v . J M W$ Farm $\mathrm{Ltd}^{2}$ and fined $£ 187,500$ under the CMCHA after the death of an employee who was crushed when an unsecured metal drum dropped from a forklift driven by one of the company's directors. The Court noted that: the Court is again confronted with an accident in which common sense would have shown that there would have been a quick, rational and successful solution to prevent this catastrophe.

Deducible from above is that despite the fact that they had obvious financial difficulties, all three companies were given such considerable high fines. In Cotswold Ltd's case, the Court of Appeal even commented that "in some cases it may be inevitable to put the firm out of business." The imposition of such heavy fines along with other varied means of imposing sanctions such as remedial orders and advertising orders is intended to encourage firms to be more rigid in implementing their health and safety policies, particularly when it comes to jobs that carry significant safety risks.

In $R v$. JMW Farm $\mathrm{Ltd}^{3}$, the respondent company was found guilty of corporate manslaughter and was fined $£ 187,500$ under the CMCHA, following the death of an employee who was crushed when an unsecured metal drum fell from a forklift, driven by one of the company's directors. The Court remarked that:

Yet again the Court is faced with an incident where common sense would have shown that a simple, reasonable and effective solution would have been available to prevent this tragedy.

Deducible from above is that all three companies were given such considerable high fines despite the fact that they had obvious financial difficulties. In the case of Cotswold Ltd, the Court of Appeal even commented that "in some cases, putting the company out of business may be inevitable". The imposition of such heavy fines along with the other varied means of imposing sanctions such as remedial orders and publicity orders are intended to encourage corporations to be more rigid with the implementation of their health and safety policies especially when it comes to jobs which bear considerable safety risks.

\section{CONCLUSION}

The core argument against corporate criminal liability has been the belief that a corporation cannot have mens rea and therefore cannot be blameworthy or guilty of a criminal offence but that the mens rea belong to the members who made the decision to take a specific course of action. However, the independent existence of a corporate will

\footnotetext{
(20 July 2012).

2 [2012] NICC 17

3 [2012] NICC 17
} 
does not always identify itself with that of the collectivity of members of the corporation. The corporation's capacity to act and decide has been recognized in contract, administrative and constitutional law. Therefore, a corporate body can be convicted of murder where the corporate body foresaw that its action could result in the death of a person. All that needs to be shown is that such act or omission was perpetrated in the course of the business of the corporation. Therefore, corporations which are convicted for the offence of manslaughter should be sentenced not only by awarding fines but be dissolved, temporary closure of the company or withdrawal of its certificate of incorporation, their names can be stuck out of the register of companies or the company can be wound up which is commensurate with the punishment of death for a natural person. Most importantly for Nigeria, the Corporate Manslaughter Bill should be further amended to encompass this significant issue of sentencing and then passed into law by the National Assembly and speedily assented to by the president to bring the law touching on on this crucial aspect of criminal liability of corporations for corporate manslaughter to be up to the moment with current global trend and expectations.

\section{REFERENCES}

Adedokun, E., (2014) Defences to Criminal Liability in Nigeria Alvari Communications Limited, Adamawa at 182.

Allen, C.K., (1933) The Nature of Crime and Society of Comparative Legislation (3rd ed). Oxford University Press, 1933) at 64.

Braithwaite, J. and Pettit, P., (1990) Not Just Deserts A Republican Theory of Criminal Justice Clarendon Press · Oxford 199 at 124.

Byam, J.T., (1982) The Economic Inefficiency of Corporate Criminal Liability 73 J. Crim. L. \& Criminology 582 , 584-85.

Emem, C.E., and Uche, A.P., (2012) A New Dawn of Corporate Criminal Liability Law in The United Kingdom: Lessons For Nigeria African Journal of Law and Criminology 2 (2) at 86-98.

Ford H.A.J, Austin R.P., Ramsay, I.M., (2001) Principles of Corporations Law (10th ed), Butterworths, Australia at 673.

Gower, L.C.B (1997) Principles of Modern Company Law (6 ${ }^{\text {th }}$ ed). London: Sweet \& Maxwell Ltd at 132.

Griffin, S., (2009) Corporate Killing, the Corporate Manslaughter and Corporate Homicide Act 2007 L.M.C.L.Q., 72 at 74.

Herring J., and Marise Cremona M., (1997) Criminal Law (2 $2^{\text {nd }}$ ed). Macmillian, London at 88.

Moohr, G.S., (2007) On the Prospects of Deterring Corporate Crime University of Houston Public Law and Legal Theory Series A-37.

Olarinde, E.S., and Udosen J (2020) Corporate Manslaughter Law in Nigeria: A Comparative Study Beijing Law Review 11(1)<https://www.scirp.org/html/23-3300898_99286.htm > accessed April 292020.

Nana, C.N., (2011) Corporate Criminal Liability in South Africa: The Need to Look Beyond Vicarious Liability Journal of African Law 55 (1) at 101.

Packer, H.L., (1964) Two Models of the Criminal Process, 113 U. Penn. L. Rev. 1.

Reasons, C., (1991) Crime Against The Environment: Some Theoretical and Practical Concerns. Vol. 34 Crim. L.Q. at 86-92.

Smith and Hogan (1993) Text, Cases and Materials on Criminal Law ( $8^{\text {th }}$ ed). Butterworths, Britain at 137.

Tom, D.F., (2005) Criminal Liabilities of Bodies Corporate in Nigeria Law Chenglo Limited, Enugu at 58.

Ugbeta E., The Lawyer Chronicles, An Assessment of The Corporate Manslaughter Bill 2015 as Drafted and its Implications For Corporate Entities in Nigeria <Thelawyerschronicle.Com/An-Assessment-Of-TheCorporate-Manslaughter-Bill-2015-As-Drafted-And-Its-Implications-For-Corporate-Entities-InNigeria/>Accessed April 302020.

Wells, C., (2001) Corporations and Criminal Responsibility (2nd ed.). Oxford: Oxford University Press at 148.

Welsh, R. S., (1946) Criminal Liability of Corporations, Law Quarterly Review at 347. 